\title{
Synthesis and property characterization of two novel side-chain isoindigo copolymers for polymer solar cells
}

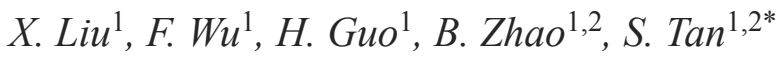 \\ ${ }^{1}$ College of Chemistry, and Key Laboratory of Environmentally Friendly Chemistry and Applications of Ministry of \\ Education, Xiangtan University, 411105 Xiangtan, PR China \\ ${ }^{2}$ Key Laboratory of Advanced Functional Polymeric Materials of College of Hunan Province, Key Laboratory of \\ Polymeric Materials \& Application Technology of Hunan Province, Xiangtan University, 411105 Xiangtan, PR China
}

Received 23 April 2015; accepted in revised form 28 June 2015

\begin{abstract}
Two novel side-chain conjugated polymers, PTBT-TID and PTBT-TTID, based on the new synthetic thiophene-benzne-thiophene (TBT) unit, side-chain isoindigo (ID) unit, and the introduced thiophene $\pi$-bridge, have been designed and synthesized. The photophysical, electrochemical and photovoltaic properties of the two polymers have been systematically investigated. The two polymers possess relatively good solubility as well as excellent thermal stability up to $380^{\circ} \mathrm{C}$, and all of the polymer solar cell (PSC) devices based on the two polymers obtain high open circuit voltage ( $\left.V_{\text {oc }}\right)$ of about $0.8 \mathrm{~V}$. The polymer solar cells based on the polymer PTBT-TID show relatively higher efficiencies than the PTBTTTID-based ones, due to the broader absorption spectrum, a relatively higher hole mobility, a lower HOMO (the highest occupied molecular orbital) energy level, a stronger IPCE (the incident photon to current conversion efficiency) response and a better microphase separation, Consequently, the device based on PTBT-TID:PC ${ }_{61} \mathrm{BM}(1: 2$, by weight) gives the best power conversion efficiency (PCE) of $2.04 \%$, with a short-circuit current density $\left(J_{\mathrm{sc}}\right)$ of $5.39 \mathrm{~mA} \cdot \mathrm{cm}^{-2}$, an open-circuit voltage $\left(V_{\mathrm{oc}}\right)$ of $0.83 \mathrm{~V}$, and a fill factor $(\mathrm{FF})$ of 0.45 .
\end{abstract}

Keywords: polymer synthesis, molecular engineering, isoindigo, thiophene bridge, polymer solar cells

\section{Introduction}

Harvesting energy directly from sunlight using photovoltaic technology has been a key solution to the growing energy crisis. In recent years, polymer solar cells (PSCs) have attracted considerable attention due to their unique advantages, such as low cost, light weight, solution processibility, and flexibility of molecular design [1-3]. The bulk heterojunction (BHJ) structure, which is composed of a photoactive blend layer of a conjugated polymer donor and a fullerene derivative acceptor, sandwiched between an anode and a cathode (at least one of them should be transparent), is one of the most successful and useful architectures in PSCs [4-8]. Recently, great advances have been made in the development of high-efficiency photovoltaic materials and device structures, especially in multiple-junction tandem solar cell and ternary solar cells. In 2015, an efficient triple-junction tandem solar cell designed by Yusoff et al. got record-high power conversion efficiency (PCE) of $11.83 \%$ in PSCs [9]. On the other hand, ternary solar cells have attracted more and more attention due to the advantages to extend the absorption spectra of large-band-gap polymers to the near IR region and to enhance light harvesting in single-junction BHJ solar cells [10-14]. However, the PCEs of PSCs still need a further promotion to meet the prospective commercial application.

So far, one appropriate approach is to design alternating donor-acceptor (D-A) low-band-gap copoly-

\footnotetext{
${ }^{*}$ Corresponding author, e-mail: tanst2008@163.com

(C) BME-PT
} 
mers through the combination of various electronrich (donors) and electron-deficient (acceptors) moieties as repeating units in the polymer backbone [15, 16]. Nevertheless, among all the existing D-A copolymers, although main chain D-A copolymers have witnessed great success for achieving highly efficient PSCs, they may suffer from lower hole mobility due to the influence of the acceptor units on the polymer main chain [17]. Thus, a new type of distinctive polymers with conjugated side chains or groups emerged, and they possess excellent features, such as a better overlap of absorption spectra with the solar spectrum, excellent solubility in common device processing solvent such as chlorobenzene (CB) or dichlorobenzene (DCB), and suitable miscibility with the fullerene acceptor $\left(\mathrm{PC}_{61} \mathrm{BM}\right)$, thus the side-chain polymers have demonstrated prominent device performances in PSCs [18].

To further manipulate stereo-structure and photoelectronic properties of conjugated polymers, some $\pi$-conjugated bridges, especially thiophene or alkylthiophene units, are inserted between donor (D) and acceptor (A) moieties to produce new D- $\pi$-A conjugated copolymers. $\pi$-Conjugated bridges crucially impact the electronic structures of polymer main chains and the interactions between D and A units; therefore, they remarkably affect the stereostructure and consequently the photophysical, electrochemical, charge transport, and photovoltaic properties of $D-\pi$-A conjugated copolymers $[19,20]$.

Isoindigo (ID), which contains two strong electrondeficient lactam rings with a planar geometry, is a useful monomer for the design and synthesis of alternating D-A low-band-gap conjugated polymers for photovoltaic device applications [21, 22]. Many IDbased polymers exhibited intense and broad absorption, which is beneficial to achieving high photovoltaic performances in PSCs [23]. And the sidechain ID unit has been reported by our group for the first time, wherein the inverted device based on PBDT-TID obtained a high PCE of $6.51 \%$ [24].

Benzodithiophene (BDT) unit is widely used in photovoltaic devices because of its symmetrical planar conjugated structure and excellent photovoltaic performance. While in this manuscript, we introduced a new donor similar to the BDT unit, thiophene-2,5bis((2-ethylhexyl)oxy)benzene-thiophene (TBT) unit, united with the side-chain ID unit, designing and synthesizing two novel side-chain polymers (PTBTTID and PTBT-TTID), as shown in Figure 1. Unlike the BDT unit, benzene and thiophene moieties were connected by carbon-carbon single bond in TBT unit, which increased the torsion degree of donor unit, resulting in a lower HOMO (the highest occupied molecular orbital) energy level and then a higher open-circuit voltage $\left(V_{\text {oc }}\right)$ value. And a side-chain ID unit was introduced as an acceptor unit to get broad absorption spectra and good photovoltaic performance. Additionally, a thiophene unit was applied as $\pi$-conjugated bridge to broaden the absorption spectra and adjust energy level. Next, the photophysical, electrochemical and photovoltaic properties of two polymers were systematically investigated.

\section{Experimental section}

\subsection{Materials}

All the chemicals were purchased from Alfa Aesar and Chem Greatwall Chemical Company (Wuhan, China) and used without further purification. Toluene and tetrahydrofuran (THF) were dried and distilled over sodium and benzophenone. N,N-Dimethylformamide (DMF) was dried over and distilled from $\mathrm{CaH}_{2}$ under an atmosphere of dry nitrogen. Phosphorus oxychloride and 1,2-dichloroethane were atmospheric distillation. All other commercially available materials were used as received unless noted otherwise. 2,5-Dibromothiophene-3-carbaldehyde (1), tributyl(thiophen-2-yl)stannane (2), (E)-5-(1,1'- bis(2ethylhexyl)-2,2'-dioxo-[3,3'-biindolinylidene]-6-yl) thiophene-2-carbaldehyde (8), (E)-6-(5-((E)-2-(2,5dibromothiophen-3-yl)vinyl)thiophen-2-yl)-1,1'bis(2-ethylhexyl)-[3,3'-biindolinylidene]-2,2'-dione (M1) and (5,5'-(2,5-bis((2-ethylhexyl)oxy)-1,4phenylene) bis(thiophene-5,2-diyl))bis(trimethylstannane) (M3) were prepared according to literature procedures [24-26].

\subsection{Synthesis}

The synthetic routes and molecular structures of two polymers are shown in Figure 1. The detailed synthetic processes are as follows.

\subsection{1. $\left[2,2^{\prime}: 5^{\prime}, 2^{\prime \prime}\right.$-Terthiophene]-3'-carbaldehyde (3)}

The compound 3 was synthesized by Stille coupling reaction. Compound 1 (6.00 g, $22.22 \mathrm{mmol})$ and compound 2 (24.85 g, $66.66 \mathrm{mmol})$ were dissolved in anhydrous toluene $(120 \mathrm{~mL})$ and deoxygenated with nitrogen for $15 \mathrm{~min}$. $\mathrm{Pd}\left(\mathrm{PPh}_{3}\right)_{4}(230 \mathrm{mg}, 0.67 \mathrm{mmol})$ was then added under nitrogen and the mixture was again flushed with nitrogen for $30 \mathrm{~min}$. Then the 


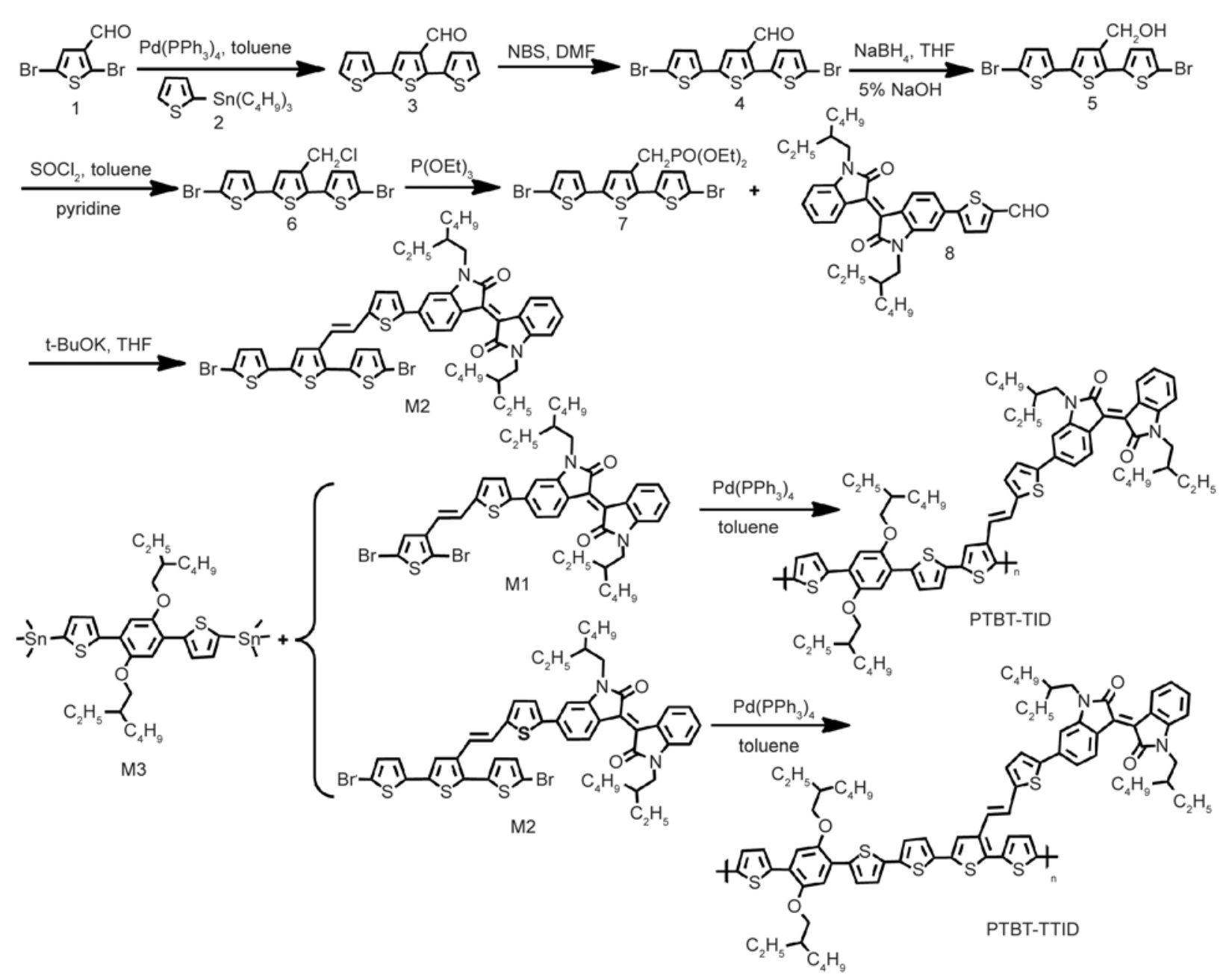

Figure 1. Synthetic routes and molecular structures of the two polymers PTBT-TID and PTBT-TTID

reaction mixture was stirred at $110^{\circ} \mathrm{C}$ for 2 days under nitrogen atmosphere. After cooled to room temperature, the mixture was poured into water $(100 \mathrm{~mL})$ and extracted with dichloromethane. The organic phase was washed with water and dried over anhydrous $\mathrm{MgSO}_{4}$. After concentration, the crude product was purified on silica gel chromatography using a petroleum ether/dichloromethane mixture ( $1 / 1$ by volume) as eluent to afford a yellow liquid (4.49 g, 73.2\%). ${ }^{1} \mathrm{H} \mathrm{NMR}\left(\mathrm{CDCl}_{3}, 400 \mathrm{MHz}\right.$,

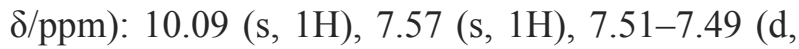
1H), 7.31-7.23 (m, 3H), 7.17-7.16 (d, 1H), 7.06-7.05 (d, $1 \mathrm{H})$. GC-MS $\left(\mathrm{C}_{13} \mathrm{H}_{8} \mathrm{OS}_{3}\right) \mathrm{m} / \mathrm{z}$ : calcd for 276.4; found 276.9 .

\subsubsection{5,5"-Dibromo-[2,2':5',2"'-terthiophene]- 3'-carbaldehyde (4)}

Compound 3 ( $4.49 \mathrm{~g}, 16.25 \mathrm{mmol}$ ) was dissolved in DMF $(50 \mathrm{~mL})$. The mixture of N-bromosuccinimide (NBS) (5.79 g, $32.50 \mathrm{mmol})$ in DMF (30 mL) was added dropwise to the solution and the solution was stirred at $30^{\circ} \mathrm{C}$ till a large amount of yellow solid dis- solved. Then, the solid was washed by methyl alcohol then dried in vacuum drying oven for one day to afford a light yellow liquid (6.80 g, 96.1\%). ${ }^{1} \mathrm{H}$ NMR $\left(\mathrm{CDCl}_{3}, 400 \mathrm{MHz}, \delta / \mathrm{ppm}\right): 10.02(\mathrm{~s}, 1 \mathrm{H}), 7.48(\mathrm{~s}$, 1H), 7.13-7.12 (d, 1H), 7.09-7.08 (d, 1H), 7.02-7.01 $(\mathrm{d}, 1 \mathrm{H}), 6.97-6.96(\mathrm{~d}, 1 \mathrm{H})$. MALDI-TOF MS $\left(\mathrm{C}_{13} \mathrm{H}_{6} \mathrm{Br}_{2} \mathrm{OS}_{3}\right) \mathrm{m} / \mathrm{z}$ : calcd for 434.190 ; found 433.867.

\subsection{3. (5,5"-Dibromo-[2,2':5',2"-terthiophen]-3'- yl)methanol (5)}

Compound 4 ( $3.00 \mathrm{~g}, 6.91 \mathrm{mmol})$ was dissolved in THF $(80 \mathrm{~mL})$, and the sodium borohydride $(5.23 \mathrm{~g}$, $138.19 \mathrm{mmol}$ ) dissolved in 5\% sodium hydroxide solution $(20 \mathrm{~mL})$ was added dropwise. After that, the reaction mixture was stirred at room temperature for two hours. Then the mixture was extracted with $\mathrm{CH}_{2} \mathrm{Cl}_{2}$ and washed with salt water. The organic phase was dried over anhydrous $\mathrm{MgSO}_{4}$ and the solvent was removed by rotary evaporation. The crude product was dried in vacuum drying oven for half an hour to afford a yellow solid (2.65 g, 87.9\%) 
without further purification. MALDI-TOF MS $\left(\mathrm{C}_{13} \mathrm{H}_{8} \mathrm{Br}_{2} \mathrm{OS}_{3}\right) \mathrm{m} / \mathrm{z}$ : calcd for 436.210 ; found 435.834

\subsubsection{5,5"-Dibromo-3'-(chloromethyl)- $2,2^{\prime}: 5^{\prime}, 2^{\prime \prime}$-terthiophene (6)}

Under nitrogen atmosphere, to a solution of compound $5(2.55 \mathrm{~g}, 5.83 \mathrm{mmol})$ and pyridine $(2.9 \mathrm{~mL}$, $35.01 \mathrm{mmol})$ in toluene $(100 \mathrm{~mL})$, anhydrous thionyl chloride (4.1 mL, $58.34 \mathrm{mmol})$ was added slowly at $0^{\circ} \mathrm{C}$. Then the mixture was heated to $70^{\circ} \mathrm{C}$ for $24 \mathrm{~h}$. After cooled to room temperature, the mixture was extracted with $\mathrm{CH}_{2} \mathrm{Cl}_{2}$ and washed with water. The organic phase was dried over anhydrous $\mathrm{MgSO}_{4}$ and the solvent was removed by rotary evaporation. The crude product was purified on silica gel chromatography using petroleum ether as eluent to afford a yellow-green solid (1.03 g, 39.1\%). ${ }^{1} \mathrm{H}$ NMR $\left(\mathrm{CDCl}_{3}, 400 \mathrm{MHz}, \delta / \mathrm{ppm}\right): 7.14$ (s, $\left.1 \mathrm{H}\right), 7.11-7.10$ $(\mathrm{d}, 1 \mathrm{H}), 7.06-7.05(\mathrm{~d}, 1 \mathrm{H}), 7.02-7.01(\mathrm{~d}, 1 \mathrm{H}), 6.96-$ $6.95(\mathrm{~d}, 1 \mathrm{H}), 4.64(\mathrm{~s}, 2 \mathrm{H})$. MALDI-TOF MS $\left(\mathrm{C}_{13} \mathrm{H}_{7} \mathrm{Br}_{2} \mathrm{ClS}_{3}\right) \mathrm{m} / \mathrm{z}$ : calcd for 454.650 ; found 453.829 .

\subsubsection{Diethyl ((5,5"-dibromo-[2,2':5',2"-} terthiophen]-3'-yl)methyl)phosphonate (7) Compound 6 (0.77 g, $1.69 \mathrm{mmol})$ was dissolved in triethyl phosphite $(40 \mathrm{~mL})$. Then the reaction mixture was stirred at $160^{\circ} \mathrm{C}$ for one day under argon atmosphere. After cooled to room temperature, the redundant triethyl phosphite was removed by rotary evaporation. The crude product was purified on silica gel chromatography using a petroleum ether/ethyl acetate mixture ( $2 / 1$ by volume) as eluent to afford a yellow-green oil $(0.73 \mathrm{~g}, 77.7 \%) .{ }^{1} \mathrm{H} \mathrm{NMR}\left(\mathrm{CDCl}_{3}\right.$, $400 \mathrm{MHz}, \delta / \mathrm{ppm}): 7.13$ (s, 1H), 7.08-7.06 (d, 2H), 6.98-6.97 (d, 1H), $6.92(\mathrm{~s}, 1 \mathrm{H}), 4.12-4.05(\mathrm{~m}, 4 \mathrm{H})$, $3.26(\mathrm{~s}, 1 \mathrm{H}), 3.20(\mathrm{~s}, 1 \mathrm{H}), 1.31-1.27(\mathrm{t}, 6 \mathrm{H})$.

\subsection{6. (E)-6-(5-((E)-2-(5,5"'-dibromo-[2,2':5',2"- terthiophen]-3'-yl)vinyl)thiophen-2-yl)- 1,1'-bis(2-ethylhexyl)-[3,3'- biindolinylidene]-2,2'-dione (M2)}

Compound 7 (0.70 g, $1.26 \mathrm{mmol})$ and compound 8 $(0.75 \mathrm{~g}, 1.26 \mathrm{mmol})$ were dissolved in THF $(15 \mathrm{~mL})$ and the solution was stirred at room temperature for 30 min under nitrogen atmosphere. Then potassium tert-butoxide $(0.21 \mathrm{~g}, 1.89 \mathrm{mmol})$ was dissolved in THF $(25 \mathrm{~mL})$ and added dropwise to the solution.
The reaction mixture was stirred for $5 \mathrm{~h}$ at room temperature, and then heated to $50^{\circ} \mathrm{C}$ for twelve hours. After cooled to room temperature, water was added for quenching the reaction, and the aqueous layer was then extracted with $\mathrm{CH}_{2} \mathrm{Cl}_{2}$. The organic layer was washed with dilute aqueous $\mathrm{HCl}$ solution and dried over $\mathrm{MgSO}_{4}$. Solvent was removed by rotary evaporation. The crude product was purified on silica gel chromatography using a petroleum ether/ dichloromethane mixture ( $3: 1$ by volume) as eluent to get a dark red solid $(0.12 \mathrm{~g}, 9.5 \%) .{ }^{1} \mathrm{H}$ NMR $\left(\mathrm{CDCl}_{3}, 400 \mathrm{MHz}, \delta / \mathrm{ppm}\right)$ : 9.21-9.15 (m, 2H), 7.38$7.31(\mathrm{~m}, 4 \mathrm{H}), 7.18(\mathrm{~s}, 1 \mathrm{H}), 7.14-7.13(\mathrm{~d}, 3 \mathrm{H}), 7.08$ $7.06(\mathrm{~d}, 1 \mathrm{H}), 7.03-6.94(\mathrm{~m}, 4 \mathrm{H}), 6.78(\mathrm{~s}, 1 \mathrm{H}), 3.75-$ $3.69(\mathrm{~m}, 4 \mathrm{H}), 1.89(\mathrm{~s}, 2 \mathrm{H}), 1.43-1.28(\mathrm{~m}, 16 \mathrm{H})$, 1.02-0.91 (m, 12H). ${ }^{13} \mathrm{C} \mathrm{NMR} \mathrm{(100} \mathrm{MHz,} \mathrm{CDCl}_{3}$, $\delta / \mathrm{ppm}): 168.54,168.33,145.76,145.08,143.34$, $143.24,137.39,136.29,135.45,132.61,132.58$, $132.07,130.78,130.35,129.74,127.95,127.25$, 124.94, 124.43, 124.05, 122.08, 121.89, 121.17, $121.10,118.99,113.48,111.86,108.09,104.60$, $44.22,44.10,37.81,37.66,30.92,30.82,29.72$, $28.87,28.81,24.33,24.16,23.10,14.11,14.08$, 10.92, 10.74. MALDI-TOF MS $\left(\mathrm{C}_{50} \mathrm{H}_{5} 0 \mathrm{Br}_{2} \mathrm{~N}_{2} \mathrm{O}_{2} \mathrm{~S}_{4}\right)$ $\mathrm{m} / \mathrm{z}$ : calcd for 999.010 ; found 999.106 .

\subsubsection{Polymerization for PTBT-TID}

The monomer M1 (97 mg, $0.12 \mathrm{mmol}$ ) and monomer M3 (96 mg, $0.12 \mathrm{mmol}$ ) were dissolved in anhydrous toluene $(5 \mathrm{~mL})$ and deoxygenated with nitrogen for $15 \mathrm{~min} . \mathrm{Pd}\left(\mathrm{PPh}_{3}\right)_{4}(6.7 \mathrm{mg}, 0.006 \mathrm{mmol})$ was then added under nitrogen and the mixture was again flushed with nitrogen for $30 \mathrm{~min}$. Then the reaction mixture was stirred at $110^{\circ} \mathrm{C}$ for 3 days under nitrogen atmosphere. Finally, the reaction mixture was cooled to room temperature and slowly added to methanol $(150 \mathrm{~mL})$. The precipitate was collected by filtration from methanol and further purified by Soxhlet extraction with methanol, acetone, petroleum ether, and chloroform in sequence. The chloroform fraction was evaporated by rotary evaporation. The final product was obtained as a black red solid (110 mg, 79.7\%). ${ }^{1} \mathrm{H} \mathrm{NMR}\left(\mathrm{CDCl}_{3}, 400 \mathrm{MHz}\right.$,

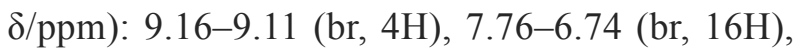
4.14-4.08 (br, 4H), 3.71-3.64 (br, 4H), 1.97-1.95 (br, 4H), 1.78-1.30 (br, 32H), 0.91 (br, 24H). Anal. Calcd for $\mathrm{C}_{72} \mathrm{H}_{86} \mathrm{~N}_{2} \mathrm{O}_{4} \mathrm{~S}_{4}$ : C, 73.84; $\mathrm{H}, 7.35 ; \mathrm{N}$, 2.39; S, 10.94. Found: C, 73.44; H, 7.53; N, 2.39; S, 11.05. $M_{\mathrm{n}}=25.7 \mathrm{KDa}, \mathrm{PDI}=2.2$. 


\subsubsection{Polymerization for PTBT-TTID}

Following the similar method as PTBT-TID, PTBTTTID was synthesized from monomer M2 $(99 \mathrm{mg}$, $0.099 \mathrm{mmol})$ and monomer $\mathbf{M 3}(82 \mathrm{mg}, 0.099 \mathrm{mmol})$, dried toluene $(5 \mathrm{~mL})$ and $\mathrm{Pd}\left(\mathrm{PPh}_{3}\right)_{4}(5.7 \mathrm{mg}$, $0.005 \mathrm{mmol})$. A black red solid was collected (120 mg, 88.9\%). ${ }^{1} \mathrm{H}$ NMR $\left(\mathrm{CDCl}_{3}, 400 \mathrm{MHz}\right.$,

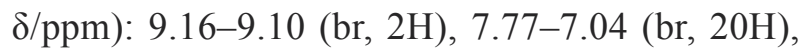
4.14-4.05 (br, 4H), 3.67-3.54 (br, 4H), 1.95-1.93 (br, 4H), 1.80-1.30 (br, 32H), 1.06-0.90 (br, 24H). Anal. Calcd for $\mathrm{C}_{80} \mathrm{H}_{90} \mathrm{~N}_{2} \mathrm{O}_{4} \mathrm{~S}_{6}: \mathrm{C}, 71.96 ; \mathrm{H}, 6.74 ; \mathrm{N}$, 2.09; S, 14.39. Found: C, 71.56; H, 6.96; N, 2.08; S, 14.45. $M_{\mathrm{n}}=12.8 \mathrm{KDa}, \mathrm{PDI}=1.7$.

\subsection{Instruments and characterizations}

Nuclear magnetic resonance (NMR) spectra were measured with Bruker AVANCE 400 spectrometer. The elemental analysis was performed with an Elementar Vario EL III element analyzer for $\mathrm{C}, \mathrm{H}, \mathrm{N}$, and S. MALDI-TOF mass spectrometric measurements were performed on Bruker Autoflex III. UV-Visible (UV-Vis) absorption spectra of the polymers were conducted on a Perkin-Elmer Lamada 25 UV-VisNIR spectrometer. The average molecular weight and polydispersity index (PDI) of the polymers were determined using Waters 1515 gel permeation chromatography (GPC) analysis with THF as eluent and polystyrene as standard. Thermogravimetric analysis (TGA) measurement was conducted on a Netzsch TG 209 analyzer under nitrogen at a heating rate of $20^{\circ} \mathrm{C} \cdot \mathrm{min}^{-1}$. Electrochemical redox potentials were obtained by cyclic voltammetry (CV) using a threeelectrode configuration and an electrochemistry workstation (ZAHNER ZENNIUM) at a scan rate of $50 \mathrm{mV} \cdot \mathrm{s}^{-1}$. CV was conducted on an electrochemistry workstation with the thin film on a Pt plate as the working electrode, Pt slice as the counter electrode, and $\mathrm{Ag} / \mathrm{AgCl}$ electrode as the reference electrode. The supporting electrolyte is $0.1 \mathrm{M}$ tetra-nbutylammonium hexafluorophosphate $\left(\mathrm{Bu}_{4} \mathrm{NPF}_{6}\right)$ in anhydrous acetonitrile solution. All AFM measurements were performed on a Digital Instruments Enviro Scope in a tapping mode.

\subsection{Fabrication and characterization of PSCs}

The structure of the solar cells was indium tin oxide (ITO) $/ \mathrm{MoO}_{3}(20 \mathrm{~nm}) /$ polymer: $\mathrm{PC}_{61} \mathrm{BM}(\sim 100 \mathrm{~nm}) /$ $\operatorname{LiF}(0.5 \mathrm{~nm}) / \mathrm{Al}(100 \mathrm{~nm})$. The PSC devices were fabricated with ITO glass as a positive electrode and
$\mathrm{LiF} / \mathrm{Al}$ as a negative electrode. The ITO glass was pre-cleaned and then modified by a thin layer of $\mathrm{MoO}_{3}$, which was deposited on ITO surface by vacuum evaporation under $5 \cdot 10^{-4} \mathrm{~Pa}$. The photoactive layer was prepared by spin-coating a blend solution of polymer and $\mathrm{PC}_{61} \mathrm{BM}$ in $\mathrm{CB}$ on the surface of ITO/ $\mathrm{MoO}_{3}$ substrate. Then, the $\mathrm{LiF} / \mathrm{Al}$ cathode was deposited on the polymer layer by vacuum evaporation under $5 \cdot 10^{-4} \mathrm{~Pa}$. The accurate area of every device is $3.8 \mathrm{~mm}^{2}$, defined by the overlap of the ITO and metal electrode. The current density-voltage $(J-V)$ curves were measured by a Keithley 2602 Source Meter under $100 \mathrm{~mW} \cdot \mathrm{cm}^{-2}$ standard AM $1.5 \mathrm{G}$ spectrum using a Sol $3 \mathrm{~A}$ Oriel solar simulator. The incident light intensity was calibrated using a standard Si solar cell. The measurement of monochromatic incident photon-to-current conversion efficiency (IPCE) was performed using a Zolix Solar Cell Scan 100 QE/IPCE measurement system.

\section{Results and discussion \\ 3.1. Synthesis}

The detailed synthetic routes of monomer M2 and target copolymers were outlined in Figure 1. The compound 3 was synthesized by Stille coupling reaction. Compound $\mathbf{4}$ was gained by a bromination reaction. The compound 5 was obtained via a reduction reaction and subsequently transformed into compound 6 by a chlorination reaction. Compound 7 was synthesized by Arbuzov reaction. Then the monomer M2 was obtained through Wittig-Horner reaction. Finally, two copolymers (PTBT-TID and PTBTTTID) were synthesized by Stille coupling polymerization using $\operatorname{Pd}(0)$ as catalyst under nitrogen atmosphere. After the purification of the crude polymers to remove oligomeric materials by Soxhlet extraction with methanol, acetone, petroleum ether, and chloroform, the dark-red colored polymers were obtained. The structures of the monomers and copolymers were confirmed by ${ }^{1} \mathrm{H} \mathrm{NMR},{ }^{13} \mathrm{C} \mathrm{NMR}$, and MALDI-TOF MS. The copolymers were found to have good solubility in most of the organic solvents such as chloroform, toluene, $\mathrm{CB}$, and o-dichlorobenzene $(\mathrm{ODCB})$ at room temperature. The numberaverage molecular weight $\left(M_{\mathrm{n}}\right)$ and polydispersity index (PDI) are $25.7 \mathrm{KDa}$ and 2.2 for PTBT-TID, 12.8 KDa and 1.7 for PTBT-TTID (Table 1), determined by gel permeation chromatography (GPC) with THF as an eluent. 
Table 1. Molecular weights and thermal properties of two copolymers

\begin{tabular}{|c|c|c|c|c|c|}
\hline Copolymers & $\begin{array}{c}\text { Yields } \\
{[\%]}\end{array}$ & $\begin{array}{c}\mathbf{M}_{\mathrm{n}}{ }^{\mathrm{a}} \\
{\left[\mathrm{Kg} \cdot \mathrm{mol}^{-1}\right]}\end{array}$ & $\begin{array}{c}\mathbf{M}_{\mathbf{w}}{ }^{\mathrm{b}} \\
{\left[\mathrm{Kg} \cdot \mathrm{mol}^{-1}\right]}\end{array}$ & $\mathbf{P D I}^{\mathbf{c}}$ & $\begin{array}{l}\mathbf{T}_{\mathbf{d}}{ }^{\mathrm{d}} \\
{\left[{ }^{\circ} \mathbf{C}\right]}\end{array}$ \\
\hline PTBT-TID & 79.7 & 25.7 & 57.0 & 2.2 & 381 \\
\hline PTBT-TTID & 88.9 & 12.8 & 22.1 & 1.7 & 388 \\
\hline
\end{tabular}

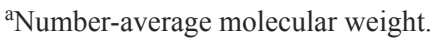

${ }^{\mathrm{b}}$ Weight-average molecular weight.

${ }^{\mathrm{c}} M_{\mathrm{w}} / M_{\mathrm{n}}$.

${ }^{\mathrm{d}}$ Decomposition temperature ( $5 \%$ weight loss) determined by thermal gravimetric analysis under nitrogen.

\subsection{Thermal properties}

The polymers were analyzed by thermal gravimetric analysis (TGA) and the results were summarized in Table 1. The polymers PTBT-TID and PTBTTTID revealed high decomposition temperatures ( $T_{\mathrm{d}}, 5 \%$ weight loss) of 381 and $388^{\circ} \mathrm{C}$, respectively (Figure 2), indicating that the two polymers possessed excellent thermal and morphology stability, fully ensuring their application in PSCs.

\subsection{Optical properties}

The UV-Vis absorption spectra of the two copolymers PTBT-TID and PTBT-TTID in (a) diluted

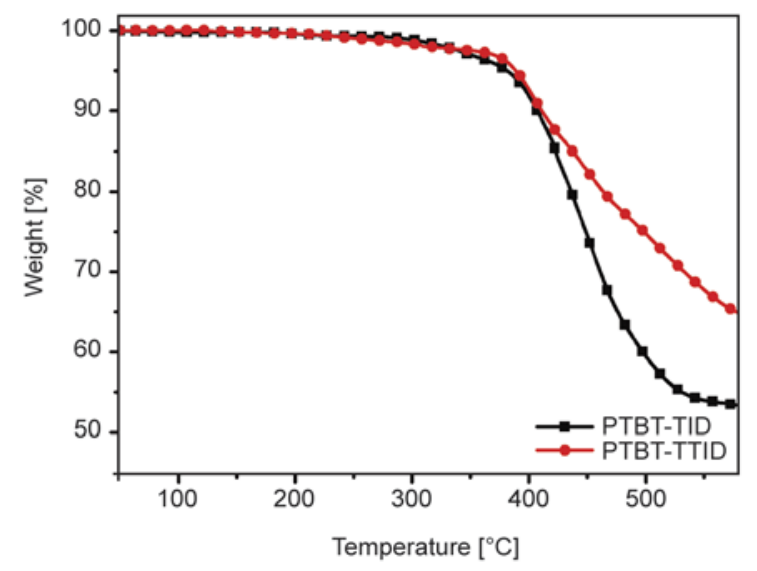

Figure 2. TGA curves of two copolymers with the scan rate of $20^{\circ} \mathrm{C} \mathrm{m^{-1 }}$

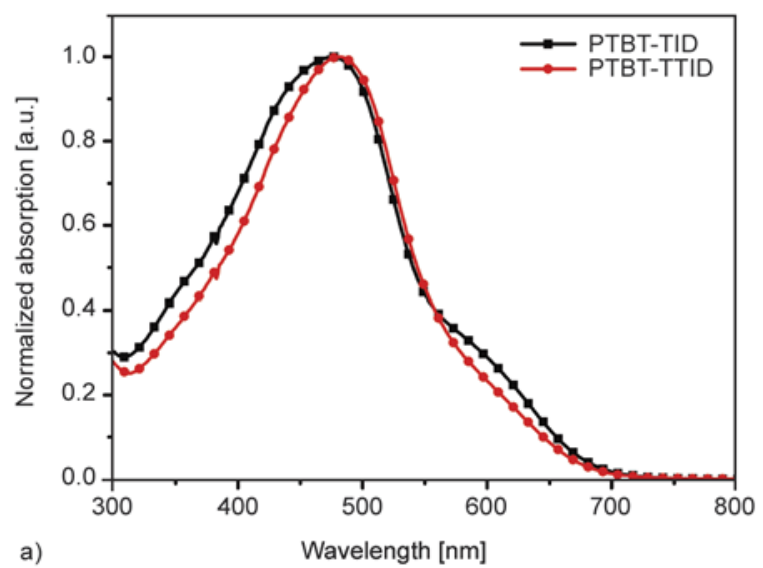

chloroform solutions $\left(0.01 \mathrm{mg} \cdot \mathrm{mL}^{-1}\right)$ and (b) solid films are shown in Figure 3, and the corresponding data are listed in Table 2. In diluted chloroform solution (Figure 3a), due to the overlap of the $\pi-\pi^{*}$ transition and intramolecular charge transfer (ICT) bands, both of the two copolymers showed one broad absorption band covering the wavelength range from 300 to $700 \mathrm{~nm}$ [27]. The maximum absorption wavelength $\left(\lambda_{\max }\right)$ of PTBT-TID and PTBT-TTID appeared at 475 and $481 \mathrm{~nm}$, and the corresponding maximum molar extinction coefficients $(\varepsilon)$ were $4.73 \cdot 10^{4}$ and $4.95 \cdot 10^{4} \mathrm{M}^{-1} \cdot \mathrm{cm}^{-1}$, respectively. Polymer PTBT-TTID exhibited a slight increase in $\varepsilon$ with a positive impact on the short-circuit photocurrent density $\left(J_{\mathrm{sc}}\right)$. Generally, relatively larger $\varepsilon$ value can enhance the $J_{\mathrm{sc}}$ [28], but the $\varepsilon$ value of PTBTTTID was only $0.22 \cdot 10^{4} \mathrm{M}^{-1} \cdot \mathrm{cm}^{-1}$ larger than PTBTTID. However, the absorption spectra of PTBT-TID were broader than that of PTBT-TTID, resulting in an apparently higher integrated current density in PTBT-TID-based device (see Figure 6a). As a result, PTBT-TID should get a higher $J_{\text {sc }}$ than PTBTTTID.

In addition, as shown in Figure $3 b$, the maximum absorption peaks in thin films were observed to approximately red-shift by 35 and $27 \mathrm{~nm}$ with respect to those in chloroform solution for PTBT-TID and

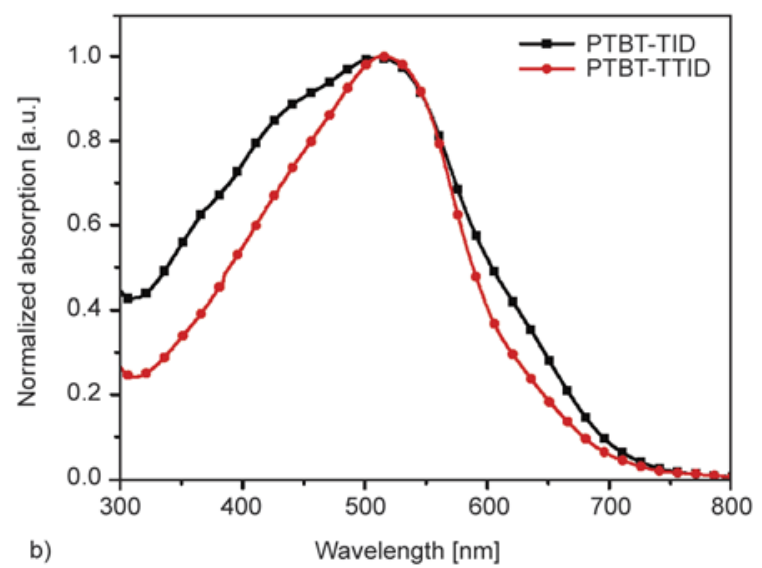

Figure 3. UV-Vis absorption spectra of two copolymers in (a) diluted chloroform solution and (b) thin films 
Table 2. Optical and electrochemical properties of the two copolymers

\begin{tabular}{|l|c|c|c|c|c|c|}
\hline \multicolumn{1}{|c|}{ Polymers } & $\begin{array}{c}\text { Solution } \\
\lambda_{\text {s,max }}{ }^{\mathbf{a}} \\
{[\mathbf{n m}]}\end{array}$ & $\begin{array}{c}\text { Film } \\
\lambda_{\mathbf{f , m a x}} \mathbf{b} \\
{[\mathbf{n m}]}\end{array}$ & $\begin{array}{c}\mathbf{E}_{\mathbf{g}}^{\text {opt c }} \\
{[\mathbf{e V}]}\end{array}$ & $\begin{array}{c}\mathbf{H O M O}^{\mathbf{d}} \\
{[\mathbf{e V}]}\end{array}$ & $\begin{array}{c}\mathbf{L U M O}^{\mathbf{e}} \\
{[\mathbf{e V}]}\end{array}$ & $\begin{array}{c}\mathbf{E}_{\mathbf{g}}^{\text {ec f }} \\
{[\mathbf{e V}]}\end{array}$ \\
\hline PTBT-TID & 475 & 510 & 1.79 & -5.33 & -3.59 & 1.74 \\
\hline PTBT-TTID & 481 & 514 & 1.92 & -5.22 & -3.61 & 1.61 \\
\hline
\end{tabular}

${ }^{\text {a}}$ Dilute chloroform solution.

${ }^{\mathrm{b}}$ Thin film spin-cast from chloroform solution.

'Optical band gap determined from the onset of absorption in the solid state.

${ }^{\mathrm{d}} \mathrm{HOMO}=-\mathrm{e}\left(E_{\mathrm{ox}}+4.22\right)[\mathrm{eV}]$.

${ }^{\mathrm{e}} \mathrm{LUMO}=-\mathrm{e}\left(E_{\mathrm{red}}+4.22\right)[\mathrm{eV}]$.

${ }^{\mathrm{f}} E_{\mathrm{g}}^{\mathrm{ec}}=-\mathrm{e}\left(E_{\mathrm{HOMO}}-E_{\mathrm{LUMO}}\right)[\mathrm{eV}]$.

PTBT-TTID, respectively, indicating the presence of aggregation or orderly $\pi-\pi$ stacking in the solid state [29, 30]. Compared to PTBT-TTID film, PTBT-TID film showed a more red-shifted absorption peak than that in solution. Besides, PTBT-TID demonstrated a shoulder peak in the absorption range of 550-700 nm, while no apparent shoulder peak in the corresponding band could be observed for PTBTTTID. These results indicated that PTBT-TID film formed a stronger molecular stacking than PTBTTTID film [31], leading to an improved light absorption in long wavelength range. Simultaneously, it implied that PTBT-TID film would possess a higher hole-transporting ability. Thus, the polymer PTBTTID should obtain a higher $J_{\mathrm{sc}}$ than PTBT-TTID. The optical band gaps $\left(E_{\mathrm{g}}^{\mathrm{opt}}\right)$ calculated from the onset wavelengths of the film absorptions of PTBT-TID and PTBT-TTID were 1.79 and $1.92 \mathrm{eV}$, respectively.

\subsection{Electrochemical properties}

The highest occupied molecular orbital (HOMO) and lowest unoccupied molecular orbital (LUMO) energy levels of conjugated polymers are crucial for the application as photovoltaic materials in PSCs, and they can be measured from the onset oxidation and reduction potentials ( $E_{\mathrm{ox}}$ and $\left.E_{\text {red }}\right)$ in the cyclic voltammograms of the polymers [32]. Figure 4 shows the cyclic voltammograms of two copolymer films. The results of the electrochemical properties are also summarized in Table 2. The cyclic voltammograms were recorded by using a $\mathrm{Ag} / \mathrm{AgCl}$ reference electrode, which was calibrated against the redox potential of ferrocene/ferrocenium couple $\left(\mathrm{Fc} / \mathrm{Fc}^{+}\right)$, whose energy level was assumed to be $4.8 \mathrm{eV}$ below the vacuum level [19], and measured under the same condition as polymer sample to be $0.58 \mathrm{~V}$. The corresponding HOMO and LUMO energy levels of polymers were calculated according to the equation: $\mathrm{HOMO}=$

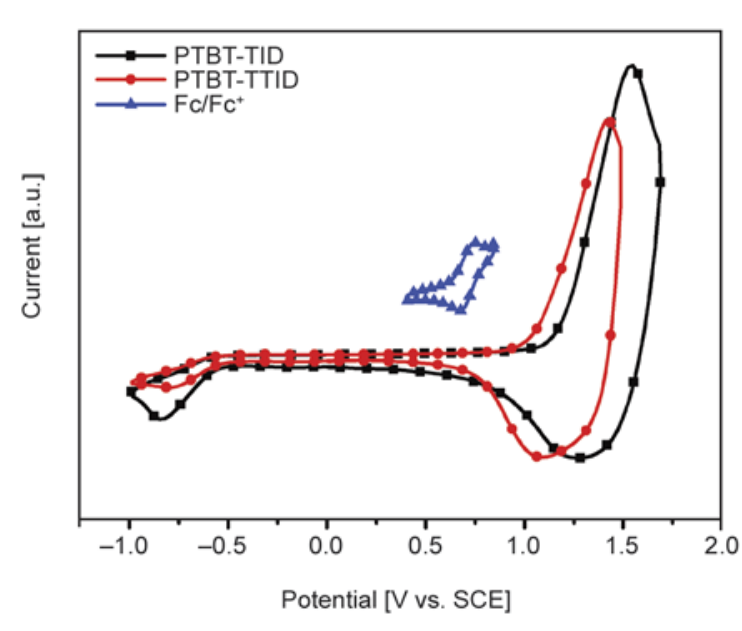

Figure 4. Cyclic voltammograms of the two copolymers

$-\mathrm{e}\left(E_{\mathrm{ox}}+4.22\right)[\mathrm{eV}], \mathrm{LUMO}=-\mathrm{e}\left(E_{\mathrm{red}}+4.22\right)[\mathrm{eV}]$, where $E_{\mathrm{ox}}$ and $E_{\text {red }}$ were the onset oxidation and reduction potential (vs. $\mathrm{Ag} / \mathrm{AgCl}$ ) of the two polymers, respectively.

As shown in Table 2, $E_{\text {ox }} / E_{\text {red }}$ of the two copolymers PTBT-TID and PTBT-TTID were $1.11 /-0.63$ and $1.00 /-0.61 \mathrm{~V}$, and the corresponding $\mathrm{HOMO} /$ LUMO energy levels were $-5.33 /-3.59$ and -5.22 / $-3.61 \mathrm{eV}$, respectively. Both of the two copolymers exhibited lower HOMO energy levels than $-5.20 \mathrm{eV}$, which was desirable for ambient stability to oxidation [33]. The deeper-lying HOMO energy level of PTBT-TID than PTBT-TTID showed that the PSC device based on PTBT-TID was expected to get better air stability [17] and higher $V_{\text {oc }}$. Their LUMO energy levels were above $0.3 \mathrm{eV}$ higher than that of $\mathrm{PC}_{61} \mathrm{BM}(-4.02 \mathrm{eV})$, indicating sufficient driving force for electron transfer from polymer to $\mathrm{PC}_{61} \mathrm{BM}$ [34]. Therefore, the HOMO and LUMO energy levels of these two copolymers were suitable for their application as donor materials in PSCs. The electrochemical bang gaps $\left(E_{\mathrm{g}}^{\mathrm{ec}}\right)$ of the two copolymers were estimated by the equation $E_{\mathrm{g}}^{\mathrm{ec}}=-\mathrm{e}\left(E_{\mathrm{HOMO}}-\right.$ $\left.E_{\mathrm{LUMO}}\right)[\mathrm{eV}]$ to be 1.74 and $1.61 \mathrm{eV}$, respectively. 
The polymer PTBT-TTID possessed a higher-lying HOMO energy level due to the addition of thiophene units. Simultaneously, the LUMO energy levels of the two polymers were similar because of the same acceptor units. Therefore, the $E_{\mathrm{g}}^{\mathrm{ec}}$ of PTBT-TTID was smaller than that of PTBT-TID. However, the $E_{\mathrm{g}}^{\mathrm{opt}}$ of the former was larger than that of the later, which could be attributed to the different aggregation structure of these two polymers films. Usually, the $E_{\mathrm{g}}^{\text {opt }}$ of a conjugated polymer decreases with the increase of the molecular stacking in film [31, 35]. For example, the $E_{\mathrm{g}}^{\text {opt }}$ of the polymer P3 $(1.70 \mathrm{eV})$ is largely smaller than its $E_{\mathrm{g}}^{\mathrm{ec}}(2.11 \mathrm{eV})$ [36]. As mentioned before, PTBT-TID film possessed strong molecular stacking, so PTBT-TID film showed a small $E_{\mathrm{g}}^{\text {opt }}$. While PTBT-TTID film possessed weak molecular stacking, so it showed a large $E_{\mathrm{g}}^{\text {opt }}$. As a

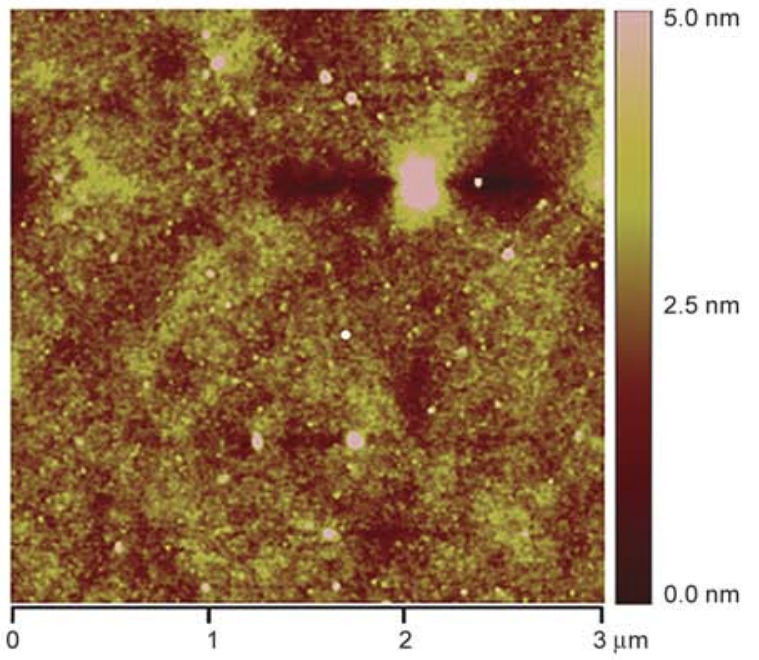

a)

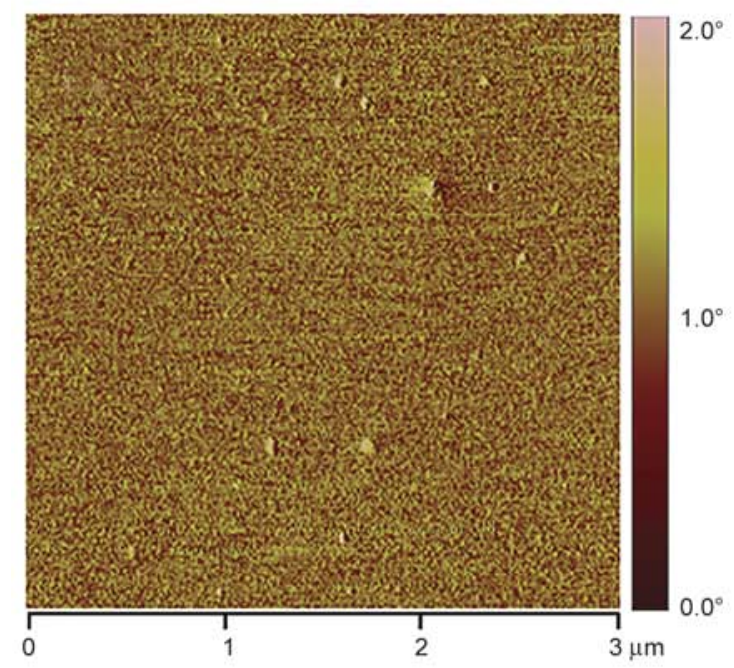

c) result, PTBT-TID film shows a smaller $E_{\mathrm{g}}^{\text {opt }}$ than that of PTBT-TTID.

\subsection{Film morphology}

To explore the effect of the morphology of active layers on the photovoltaic performances of the two copolymers, we investigated the surface morphologies of polymers $/ \mathrm{PC}_{61} \mathrm{BM}(1 / 2, \mathrm{w} / \mathrm{w})$ blends using an atomic force microscopy (AFM) in a tapping mode. As is well-known, the better morphology of the polymer could be beneficial for a higher fill factor (FF). Better morphology should include an ideal domain size of 10 20 nm of polymer and PCBM with an interpenetrating bicontinuous network, and both smaller $(<10 \sim 20 \mathrm{~nm})$ and larger $(>10 \sim 20 \mathrm{~nm})$ domain sizes of the blend films will limit charge transfer and separation [37]. Figure 5a, 5c demon-

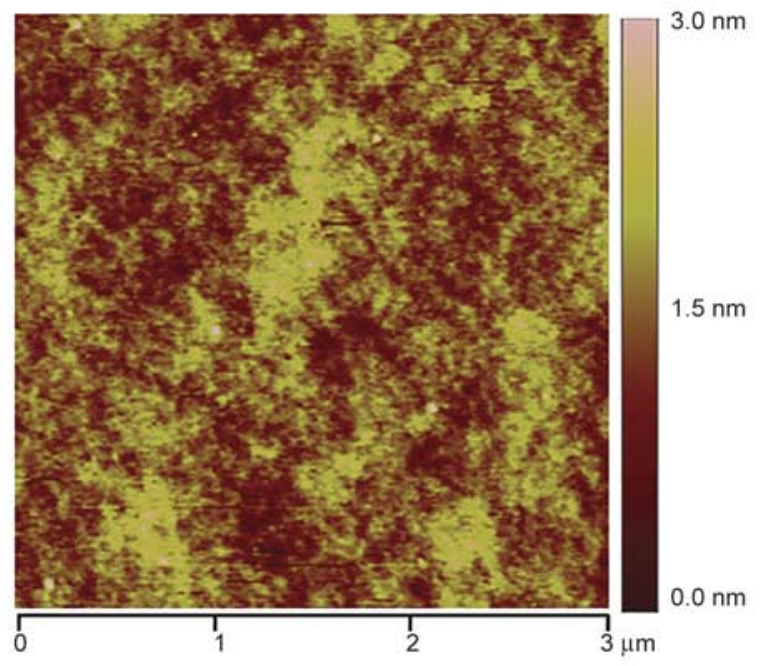

b)

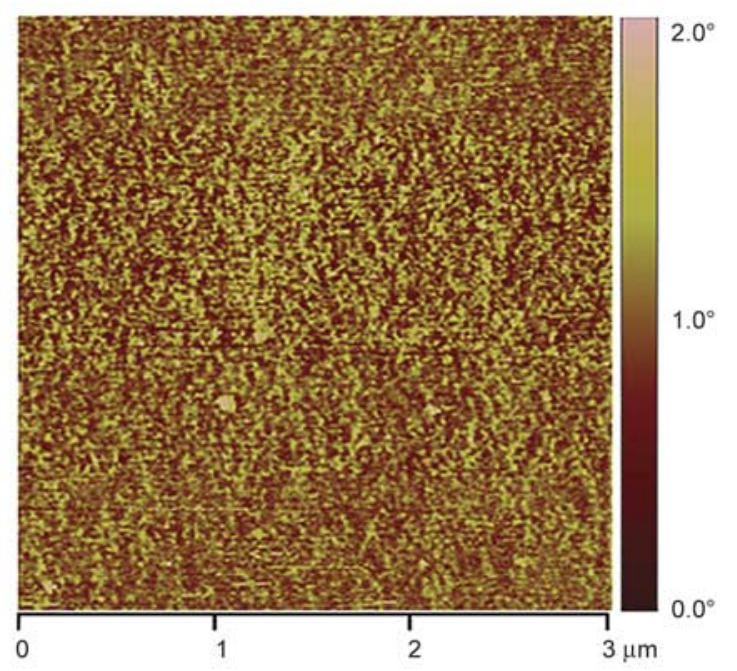

d)

Figure 5. (a, b) AFM height images and (c, d) phase images $(3 \times 3 \mu \mathrm{m})$ of copolymers: $\mathrm{PC}_{61} \mathrm{BM}(1: 2, \mathrm{w} / \mathrm{w})$. (a), (c) for PTBT-TID. (b), (d) for PTBT-TTID. 
strates the AFM height images and (Figure 5b, 5d) phase images of the active layer surfaces. The rootmean-square (rms) surface roughness for PTBTTID/PC ${ }_{61} \mathrm{BM}$ and PTBT-TTID/PC ${ }_{61} \mathrm{BM}$ film was 0.695 and $0.348 \mathrm{~nm}$, respectively. Generally, a rough surface might increase the heterojunction area and effectively reduce the charge-transport distance and at the same time provide a nano-scaled texture that further enhances internal light absorption [38, 39]. Thus, for the PTBT-TID/PC ${ }_{61} \mathrm{BM}$ film, the charge recombination at the interface was decreased which benefited the charge transport, resulting in a relatively high FF and photovoltaic performance. Furthermore, the suitable microphase separation of the PTBTTID/ $/ \mathrm{PC}_{61} \mathrm{BM}$ film could facilitate the diffusion and separation of excitons and charge transport, leading to a high $J_{\mathrm{sc}}, \mathrm{FF}$ and PCE [40]. While the greater phase segregation of the PTBT-TTID/PC ${ }_{61} \mathrm{BM}$ blends presumably arose because of poor miscibility with the fullerene, causing a larger aggregation in film and the decrease in FF and PCE [41].

\subsection{Hole mobility}

In order to get a better understanding in the influence of charge carrier transport on photovoltaic performance, the hole mobility of the target copolymers was measured by using a space charge limit current (SCLC) method under the same condition. Hole-only devices were fabricated with the configuration of ITO/PEDOT:PSS (30 nm)/Polymer:PC ${ }_{61} \mathrm{BM} / \mathrm{MoO}_{3}$ $(10 \mathrm{~nm}) / \mathrm{Al}(100 \mathrm{~nm})$. And the corresponding data of the copolymers are summarized in Table 3 . The calculated hole mobility of PTBT-TID and PTBTTTID blend films was $3.0 \cdot 10^{-4}$ and $1.4 \cdot 10^{-4} \mathrm{~cm}^{2} \cdot \mathrm{V}^{-1} \cdot \mathrm{s}^{-1}$, respectively (Table 3 ). The relatively higher hole mobility of PTBT-TID than PTBT-TTID suggested that with the introduction of excessive thiophene units, the intermolecular charge transfer was blocked, resulting in a drop in charge transporting ability of PTBT-TTID. Mean- while, this phenomenon presented that PTBT-TID could obtain a higher $J_{\text {sc }}$ than PTBT-TTID.

\subsection{Photovoltaic properties}

To study the effect of new TBT donor and thiophene $\pi$-bridge on the photovoltaic properties of the two copolymers, BHJ PSCs with the same conventional device configuration of ITO/ $\mathrm{MoO}_{3}(20 \mathrm{~nm}) /$ polymer: $\mathrm{PC}_{61} \mathrm{BM} / \mathrm{LiF}(0.5 \mathrm{~nm}) / \mathrm{Al}(100 \mathrm{~nm})$ were fabricated. Figure 6a shows the incident photon to current conversion efficiency (IPCE) spectra, (Figure $6 \mathrm{~b})$ the current density-voltage $(J-V)$ curves under the illumination of AM $1.5 \mathrm{G}, 100 \mathrm{~mW} \cdot \mathrm{cm}^{-2}$ and (Figure 6c) the $J-V$ curves in the dark for the optimized PSC devices, respectively, with the detailed photovoltaic parameters summarized in Table 3 .

We systematically investigated the performances of PSC devices based on these two copolymers under various conditions. Firstly, the blend ratios of PTBTTID:PC ${ }_{61} \mathrm{BM}$ were optimized from 1:1, 1:2 to 1:3, and the optimized device prepared at a blend ratio of 1:2 exhibited the best PCE of $1.68 \%$. Then we treated the active layers of PTBT-TID-based devices with different device-processing solvents from $\mathrm{CB}$ to ODCB. Generally, fast solvent evaporation conditions by relatively volatile $\mathrm{CB}$ induces less-ordered structure of the active layer, while the high-boiling solvent ODCB has a slower film-forming process, equal to the effect of solvent annealing, which is easy to form the photo-active layer with a better aggregation structure $[42,43]$. Thus, the ODCB-processed device based on PTBT-TID got a better PCE of $2.04 \%$. Moreover, to further optimize the device performance, 1,8-diiodooctane (DIO) as an additive was added, but no apparent improvement could be observed.

As shown in Figure 6a, the PSC device based on PTBT-TID exhibited a relatively strong IPCE response ranging from 350 to $500 \mathrm{~nm}$ with maximum IPCE value of $40 \%$ at $477 \mathrm{~nm}$, while the IPCE

Table 3. Photovoltaic parameters of PSC devices based on two copolymers

\begin{tabular}{|l|c|c|c|c|c|c|c|c|}
\hline \multicolumn{1}{|c|}{ Polymers } & $\begin{array}{c}\text { Thickness } \\
{[\mathbf{n m}]}\end{array}$ & D/A blend ratio & Solvent & $\begin{array}{c}\mathbf{J}_{\mathbf{s c}} \\
{\left[\mathbf{m A \cdot \mathbf { c m } ^ { - 2 } ]}\right.}\end{array}$ & $\begin{array}{c}\mathbf{V}_{\text {oc }} \\
{[\mathbf{V}]}\end{array}$ & $\mathbf{F F}$ & $\begin{array}{c}\mathbf{P C E}_{\text {max }}\left(\mathbf{P C E}_{\text {ave }}\right) \\
{[\mathbf{\%}]}\end{array}$ & $\begin{array}{c}\boldsymbol{\mu}_{\text {have }} \\
{\left[\mathbf{c m}^{2} \cdot \mathbf{V}^{-1} \cdot \mathbf{s}^{-\mathbf{1}}\right]}\end{array}$ \\
\hline PTBT-TID $^{\mathrm{a}}$ & 96 & $1: 1$ & $\mathrm{CB}$ & 4.45 & 0.81 & 0.37 & $1.34(1.27 \pm 0.07)$ & \\
\hline PTBT-TID $^{\mathrm{a}}$ & 98 & $1: 2$ & $\mathrm{CB}$ & 5.13 & 0.79 & 0.41 & $1.68(1.59 \pm 0.10)$ & \\
\hline PTBT-TID $^{\mathrm{a}}$ & 94 & $1: 3$ & $\mathrm{CB}$ & 4.74 & 0.84 & 0.38 & $1.49(1.47 \pm 0.01)$ & \\
\hline PTBT-TID $^{\mathrm{a}}$ & 88 & $1: 2$ & ODCB & 5.39 & 0.83 & 0.45 & $2.04(2.02 \pm 0.01)$ & $3.0 \cdot 10^{-4}$ \\
\hline PTBT-TTID $^{\mathrm{a}}$ & 86 & $1: 2$ & ODCB & 4.47 & 0.79 & 0.39 & $1.36(1.30 \pm 0.04)$ & $1.4 \cdot 10^{-4}$ \\
\hline
\end{tabular}

The structure of fabricated devices: ${ }^{\mathrm{a}} \mathrm{ITO} / \mathrm{MoO}_{3}(20 \mathrm{~nm}) /$ polymer: $\mathrm{PC}_{61} \mathrm{BM} / \mathrm{LiF}(0.5 \mathrm{~nm}) / \mathrm{Al}(100 \mathrm{~nm})$. 


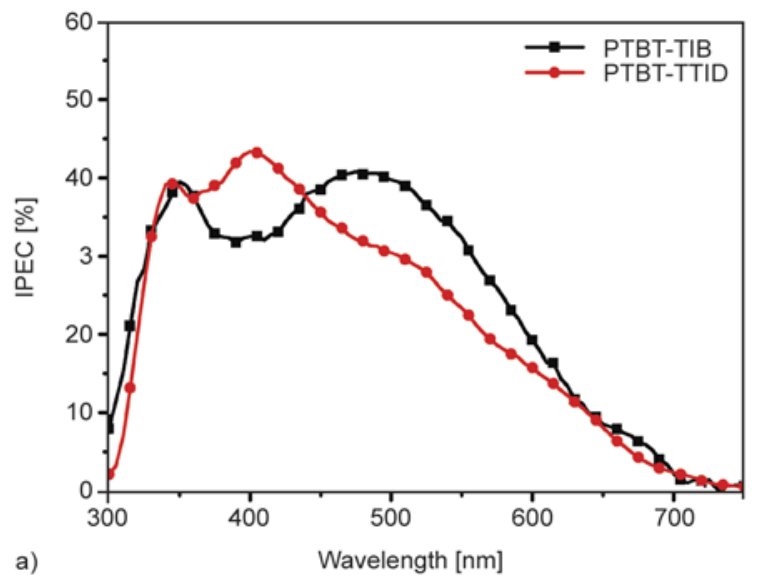

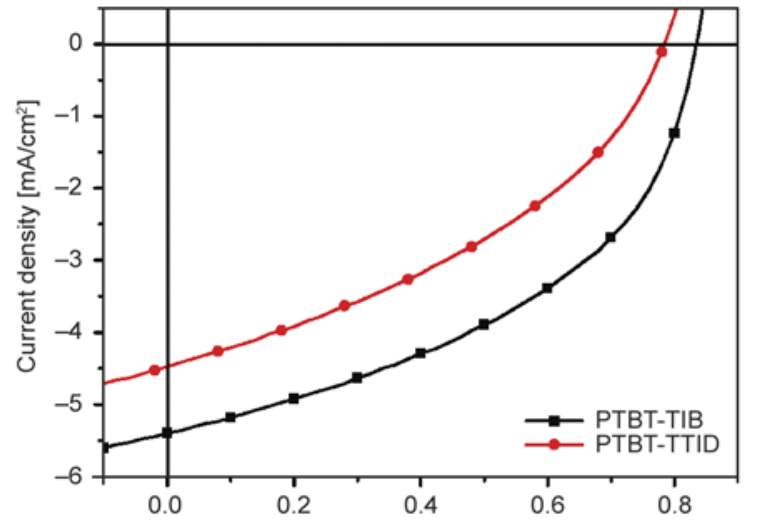

b)

Voltage $\left[\mathrm{V}_{1}\right.$

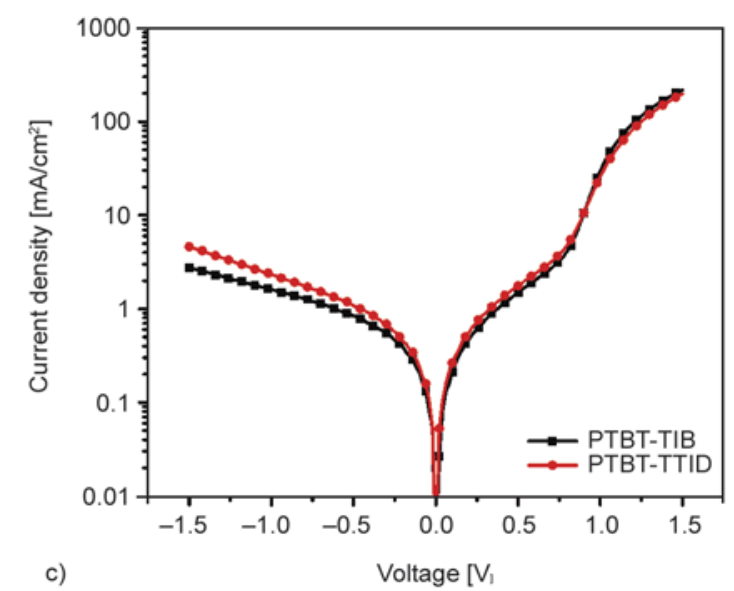

c)

Figure 6. (a) IPCE curves, (b) $J-V$ curves under the illumination of AM $1.5 \mathrm{G}, 100 \mathrm{~mW} \cdot \mathrm{cm}^{-2}$ and (c) $J-V$ curves in the dark for the optimized PSC devices based on the two copolymers

curve of PTBT-TTID-based device displayed an obvious falling tendency from the wavelength of $400 \mathrm{~nm}$, indicating its narrow spectral response range and lower absorptivity in long wave. Although the absorption spectrum shapes and maximum absorption peak positions of PTBT-TID and PTBT-TTID films were very similar, PTBT-TID showed a broader absorption spectrum with respect to PTBT-TTID, which would benefit the IPCE response. Besides, IPCE is related to not only the absorption spectra in thin film, but also the electron transport. So there is often a difference between the IPCE curves and UVVis absorption spectra $[44,45]$. These results were in good accordance with the $J_{\mathrm{sc}}$ variation obtained in $J-V$ measurements (Figure 6b). From the dark $J-V$ characteristics (Figure 6c), it was clear that the PTBT-TID-based device showed a lower leakage current (thus a higher shunt resistance) and a little smaller series resistance, resulting in a higher $J_{\mathrm{sc}}$ for PTBT-TID-based device when compared to the PTBT-TTID-based one [46].
Consequently, the PSC device based on PTBT-TID obtained a relatively higher PCE value of $2.04 \%$, with a higher $J_{\mathrm{sc}}$ of $5.39 \mathrm{~mA} \cdot \mathrm{cm}^{-2}$, a higher $V_{\text {oc }}$ of $0.83 \mathrm{~V}$, and a higher FF of 0.45 . While the device based on PTBT-TTID only got the PCE of $1.36 \%$ on the same condition.

\section{Conclusions}

In a word, based on the new TBT unit and sidechain ID unit as well as the introduction of thiophene $\pi$-bridge, two novel side-chain conjugated copolymers PTBT-TID and PTBT-TTID were designed and synthesized. Both of these two copolymers exhibited good solubility and excellent thermal stability, and all of the PSC devices based on them obtained high $V_{\mathrm{oc}}$ values around $0.8 \mathrm{~V}$. The addition of excessive thiophene units distorted the polymer backbone and then lowered the hole mobility of PTBT-TTID, resulting in a drop in PCE value. As a result, the device based on PTBT-TID showed the relatively higher $J_{\mathrm{sc}}, V_{\mathrm{oc}}$ and $\mathrm{FF}$ values, which 
resulted from a better overlap of the absorption spectrum with solar spectrum, a relatively higher hole mobility, a lower HOMO energy level, a stronger IPCE response and a better microphase separation, leading to a higher PCE of $2.04 \%$ than the device based on PTBT-TTID $(1.36 \%)$ on the same measured condition. Although the PCEs of these two copolymers are not high, the copolymers PTBTTID and PTBT-TTID have great potential application in ternary solar cells due to the good compatibility with the fullerene acceptor, resulting in the less phase separation of the active layers. And it can be expected to obtain more polymer materials with better photovoltaic performances through the further optimization and control of polymerization units in the future.

\section{Acknowledgements}

This work was supported by the National Natural Science Foundation of China (21474081), and Hunan Provincial Natural Science Foundation of China (13JJ2025).

\section{References}

[1] Li Y., Zou Y.: Conjugated polymer photovoltaic materials with broad absorption band and high charge carrier mobility. Advanced Materials, 20, 2952-2958 (2008). DOI: $10.1002 /$ adma.200800606

[2] Xu Q., Wang J., Chen S., Li W., Wang H.: Synthesis and characterization of naphthalene diimide polymers based on donor-acceptor system for polymer solar cells. Express Polymer Letters, 7, 842-851 (2013). DOI: 10.3144/expresspolymlett.2013.81

[3] Yang J., Clark N., Long M., Xiong J., Jones D. J., Yang B., Zhou C.: Solution stability of active materials for organic photovoltaics. Solar Energy, 113, 181-188 (2015).

DOI: $10.1016 /$ j.solener.2015.01.001

[4] Wang T. L., Shieh Y. T., Yang C. H., Ho T. H., Chen C. H.: Photovoltaic properties and annealing effects of a low bandgap copolymer containing dithienothiophene and benzothiadiazole units. Express Polymer Letters, 7, 63-75 (2012).

DOI: 10.3144/expresspolymlett.2013.6

[5] Zou Y., Najari A., Berrouard P., Beaupré S., Réda Aïch B., Tao Y., Leclerc M.: A thieno[3,4-c]pyrrole-4,6-dionebased copolymer for efficient solar cells. Journal of the American Chemical Society, 132, 5330-5331 (2010). DOI: $\underline{10.1021 / j a 101888 b}$
[6] Chu T-Y., Lu J., Beaupré E. S., Zhang Y., Pouliot J-R., Wakim S., Zhou J., Leclerc M., Li Z., Ding J., Tao Y.: Bulk heterojunction solar cells using thieno[3,4-c]pyrrole-4,6-dione and dithieno[3,2-b:2',3'- $d]$ silole copolymer with a power conversion efficiency of $7.3 \%$. Journal of the American Chemical Society, 133, 42504253 (2011). DOI: $10.1021 / \mathrm{ja} 200314 \mathrm{~m}$

[7] Chang C-Y., Zuo L., Yip H-L., Li Y., Li C-Z., Hsu CH., Cheng Y-J., Chen H., Jen A. K-Y.: A versatile fluoro-containing low-bandgap polymer for efficient semitransparent and tandem polymer solar cells. Advanced Functional Materials, 23, 5084-5090 (2013).

DOI: $10.1002 /$ adfm201301557

[8] Lanzi M., Paganin L., Errani F.: Synthesis, characterization and photovoltaic properties of a new thiophenebased double-cable polymer with pendent fullerene group. Polymer, 53, 2134-2145 (2012).

DOI: $10.1016 /$ j.polymer.2012.03.040

[9] Yusoff A. R. B. M., Kim D., Kim H. P., Shneider F. K., Da Silva W. J., Jang J.: A high efficiency solution processed polymer inverted triple-junction solar cell exhibiting a power conversion efficiency of $11.83 \%$. Energy and Environmental Science, 8, 303-316 (2015). DOI: 10.1039/C4EE03048F

[10] Yang Y. M., Chen W., Dou L., Chang W-H., Duan HS., Bob B., Li G., Yang Y.: High-performance multipledonor bulk heterojunction solar cells. Nature Photonics, 9, 190-198 (2015).

DOI: 10.1038/nphoton.2015.9

[11] An Q., Zhang F., Li L., Wang J., Zhang J., Zhou L., Tang W.: Improved efficiency of bulk heterojunction polymer solar cells by doping low-bandgap small molecules. ACS Applied Materials and Interfaces, 6, 65376544 (2014).

DOI: $10.1021 / \mathrm{am} 500074 \mathrm{~s}$

[12] An Q., Zhang F., Li L., Wang J., Sun Q., Zhang J., Tang W., Deng Z.: Simultaneous improvement in short circuit current, open circuit voltage, and fill factor of polymer solar cells through ternary strategy. ACS Applied Materials and Interfaces, 7, 3691-3698 (2015). DOI: $10.1021 /$ acsami.5b00308

[13] An Q., Zhang F., Zhang J., Tang W., Wang Z., Li L., Xu Z., Teng F., Wang Y.: Enhanced performance of polymer solar cells through sensitization by a narrow band gap polymer. Solar Energy Materials and Solar Cells, 118, 30-35 (2013).

DOI: $10.1016 /$ j.solmat.2013.07.050

[14] Ameri T., Khoram P., Min J., Brabec C. J.: Organic ternary solar cells: A review. Advanced Materials, 25, 4245-4266 (2013).

DOI: $\underline{10.1002 / \mathrm{adma} .201300623}$ 
[15] Pop F., Amacher A., Avarvari N., Ding J., Daku L. M. L., Hauser A., Koch M., Hauser J., Liu S., Decurtins S.: Tetrathiafulvalene-benzothiadiazoles as redox-tunable donor-acceptor systems: Synthesis and photophysical study. Chemistry - A European Journal, 19, 25042514 (2013).

DOI: $10.1002 /$ chem.201202742

[16] Deng P., Xiong J., Li S., Wu Y., Yang J., Zhang Q.: Random copolymers based on thieno[3,4-c]pyrrole4,6-dione and isoindigo building blocks for polymer solar cells. Chinese Journal of Chemistry, 32, 521-526 (2014).

DOI: $10.1002 /$ cjoc.201400316

[17] Zhang Z-G., Liu Y-L., Yang Y., Hou K., Peng B., Zhao G., Zhang M., Guo X., Kang E., Li Y.: Alternating copolymers of carbazole and triphenylamine with conjugated side chain attaching acceptor groups: Synthesis and photovoltaic application. Macromolecules, 43, 9376-9383 (2010).

DOI: $10.1021 / \mathrm{ma101491 \textrm {c }}$

[18] Hou J., Tan Z., Yan Y., He Y., Yang C., Li Y.: Synthesis and photovoltaic properties of two-dimensional conjugated polythiophenes with bi(thienylenevinylene) side chains. Journal of the American Chemical Society, 128, 4911-4916 (2006). DOI: $10.1021 / \mathrm{ja} 060141 \mathrm{~m}$

[19] Bin H., Xiao L., Liu Y., Shen P., Li Y.: Effects of donor unit and $\pi$-bridge on photovoltaic properties of $\mathrm{D}-\mathrm{A}$ copolymers based on benzo[1,2- $\left.b: 4,5-c^{\prime}\right]$-dithiophene4,8-dione acceptor unit. Journal of Polymer Science Part A: Polymer Chemistry, 52, 1929-1940 (2014). DOI: 10.1002/pola.27209

[20] Li Q., Zhong C., Huang J., Huang Z., Pei Z., Liu J., Qin J., Li Z.: Conjugated polymers with pyrrole as the conjugated bridge: Synthesis, characterization, and twophoton absorption properties. Journal of Physical Chemistry B, 115, 8679-8685 (2011).

DOI: $10.1021 /$ jp2015484

[21] Stalder R., Mei J., Reynolds J. R.: Isoindigo-based donor-acceptor conjugated polymers. Macromolecules, 43, 8348-8352 (2010). DOI: $10.1021 / \mathrm{ma} 1018445$

[22] Lei T., Cao Y., Fan Y., Liu C-J., Yuan S-C., Pei J.: High-performance air-stable organic field-effect transistors: Isoindigo-based conjugated polymers. Journal of the American Chemical Society, 133, 6099-6101 (2011). DOI: $10.1021 /$ ja111066r

[23] Mahmood K., Liu Z-P., Li C., Lu Z., Fang T., Liu X., Zhou J., Lei T., Pei J., Bo Z.: Novel isoindigo-based conjugated polymers for solar cells and field effect transistors. Polymer Chemistry, 4, 3563-3574 (2013). DOI: $10.1039 / \mathrm{c} 3$ py00341h
[24] Wang C., Zhao B., Cao Z., Shen P., Tan Z., Li X., Tan S.: Enhanced power conversion efficiencies in bulk heterojunction solar cells based on conjugated polymer with isoindigo side chain. Chemical Communications, 49, 3857-3859 (2013). DOI: $10.1039 / \mathrm{c} 3 \mathrm{cc} 40620 \mathrm{~b}$

[25] Gu Z., Tang P., Zhao B., Luo H., Guo X., Chen H., Yu G., Liu X., Shen P., Tan S.: Synthesis and photovoltaic properties of copolymers based on benzo[1,2-b:4,5- $\left.b^{\prime}\right]$ dithiophene and thiophene with different conjugated side groups. Macromolecules, 45, 2359-2366 (2012). DOI: $10.1021 / \mathrm{ma} 202399$ n

[26] Hou R., Zhao B., Wu F., Wang G., Shen T., Guo H., Zhang J., Chen H., Tan S.: Synthesis, characterization, and photovoltaic performance of the polymers based on thiophene-2,5-bis((2-ethylhexyl)oxy) benzene-thiophene. Organic Electronics, 20, 142-149 (2015). DOI: 10.1016/j.orgel.2015.02.011

[27] Patra D., Chiang C-C., Chen W-A., Wei K-I., Wu MC., Chu C-W.: Solution-processed benzotrithiophenebased donor molecules for efficient bulk heterojunction solar cells. Journal of Materials Chemistry A, 1, 7767-7774 (2013).

DOI: $10.1039 / \mathrm{c} 3$ ta11544e

[28] Dong Y., Hu X., Duan C., Liu P., Liu S., Lan L., Chen D., Ying L., Su S., Gong X., Huang F., Cao Y.: A series of new medium-bandgap conjugated polymers based on naphtho[1,2-c:5,6-c]bis(2-octyl-[1,2,3]triazole) for high-performance polymer solar cells. Advanced Materials, 25, 3683-3688 (2013).

DOI: $10.1002 / \mathrm{adma} .201301547$

[29] Spano F. C., Silva C.: H- and J-aggregate behavior in polymeric semiconductors. Annual Review of Physical Chemistry, 65, 477-500 (2014). DOI: 10.1146/annurev-physchem-040513-103639

[30] Chang W-H., Gao J., Dou L., Chen C-C., Liu Y., Yang Y.: Side-chain tunability via triple component random copolymerization for better photovoltaic polymers. Advanced Energy Materials, 4, 1300864/1-1300864/6 (2013).

DOI: 10.1002/aenm.201300864

[31] Shen P., Bin H., Zhang Y., Li Y.: Synthesis and optoelectronic properties of new D-A copolymers based on fluorinated benzothiadiazole and benzoselenadiazole. Polymer Chemistry, 5, 567-577 (2014). DOI: $10.1039 / \mathrm{c} 3$ py00968h

[32] Pommerehne J., Vestweber H., Guss W., Mahrt R. F., Bässler H., Porsch M., Daub J.: Efficient two layer LEDs on a polymer blend basis. Advanced Materials, 7, 551-554 (1995).

DOI: $10.1002 /$ adma.19950070608

[33] Thompson B. C., Kim Y-G., Reynolds J. R.: Spectral broadening in MEH-PPV:PCBM-based photovoltaic devices via blending with a narrow band gap cyanovinylene-dioxythiophene polymer. Macromolecules, 38, 5359-5362 (2005).

DOI: $10.1021 / \mathrm{ma} 0505934$ 
[34] Brédas J-L., Beljonne D., Coropceanu V., Cornil J.: Charge-transfer and energy-transfer processes in $\pi$ conjugated oligomers and polymers: A molecular picture. Chemical Reviews, 104, 4971-5004 (2004). DOI: $10.1021 / \mathrm{cr} 040084 \mathrm{k}$

[35] Wang M., Hu X., Liu L., Duan C., Liu P., Ying L., Huang F., Cao Y.: Design and synthesis of copolymers of indacenodithiophene and naphtho[1,2-c:5,6-c]bis (1,2,5-thiadiazole) for polymer solar cells. Macromolecules, 46, 3950-3958 (2013).

DOI: $10.1021 / \mathrm{ma} 400355 \mathrm{~W}$

[36] Wang N., Chen Z., Wei W., Jiang Z.: Fluorinated benzothiadiazole-based conjugated polymers for high-performance polymer solar cells without any processing additives or post-treatments. Journal of the American Chemical Society, 135, 17060-17068 (2013). DOI: $10.1021 / \mathrm{ja} 409881 \mathrm{~g}$

[37] Peng Q., Liu X., Qin Y., Zhou D., Xu J.: Thieno[3,4b]pyrazine-based low bandgap photovoltaic copolymers: Turning the properties by different aza-heteroaromatic donors. Journal of Polymer Science Part A: Polymer Chemistry, 49, 4458-4467 (2011).

DOI: $10.1002 /$ pola. 24887

[38] Chang Y-T., Hsu S-L., Chen G-Y., Su M-H., Singh T. A., Diau E. W-G., Wei K.: Intramolecular donor-acceptor regioregular poly(3-hexylthiophene)s presenting octylphenanthrenyl-imidazole moieties exhibit enhanced charge transfer for heterojunction solar cell applications. Advanced Functional Materials, 18, 2356-2365 (2008). DOI: $10.1002 / \mathrm{adfm} .200701150$

[39] Li G., Shrotriya V., Huang J., Yao Y., Moriarty T., Emery K., Yang Y.: High-efficiency solution processable polymer photovoltaic cells by self-organization of polymer blends. Nature Materials, 4, 864-868 (2005). DOI: $10.1038 /$ nmat 1500

[40] Shi Q., Fan H., Liu Y., Chen J., Ma L., Hu W., Shuai Z., Li Y., Zhan X.: Side chain engineering of copolymers based on bithiazole and benzodithiophene for enhanced photovoltaic performance. Macromolecules, 44, 4230-4240 (2011). DOI: $10.1021 / \mathrm{ma} 200576 \mathrm{y}$
[41] Jiang J-M., Chen H-C., Lin H-K., Yu C-M., Lan S-C., Liu C-M., Wei K-H.: Conjugated random copolymers of benzodithiophene-benzooxadiazole-diketopyrrolopyrrole with full visible light absorption for bulk heterojunction solar cells. Polymer Chemistry, 4, 5321-5328 (2013).

DOI: $10.1039 / \mathrm{C} 3 \mathrm{PY} 00132 \mathrm{~F}$

[42] Chu C-W., Yang H., Hou W-J., Huang J., Li G., Yang Y.: Control of the nanoscale crystallinity and phase separation in polymer solar cells. Applied Physics Letters, 92, 103306/1-103306/3 (2008). DOI: $10.1063 / 1.2891884$

[43] Liu F., Gu Y., Wang C., Zhao W., Chen D., Briseno A. L., Russell T. P.: Efficient polymer solar cells based on a low bandgap semi-crystalline DPP polymer-PCBM blends. Advanced Materials, 24, 3947-3951 (2012). DOI: 10.1002/adma.201200902

[44] Hasobe T., Imahori H., Fukuzumi S., Kamat P. V.: Light energy conversion using mixed molecular nanoclusters. porphyrin and $\mathrm{C}_{60}$ cluster films for efficient photocurrent generation. Journal of Physical Chemistry B, 107, 12105-12112 (2003). DOI: $10.1021 / \mathrm{jp} 035854 \mathrm{v}$

[45] Tezuka N., Umeyama T., Matano Y., Shishido T., Kawasaki M., Nishi M., Hirao K., Lehtivuori H., Tkachenko N. V., Lemmetyinen H., Honsho Y., Seki S., Imahori $\mathrm{H}$.: Good solvent effects of $\mathrm{C}_{70}$ cluster formations and their electron-transporting and photoelectrochemical properties. Journal of Physical Chemistry B, 114, 14287-14297 (2010). DOI: $10.1021 / \mathrm{jp} 911141 \mathrm{~s}$

[46] Savva A., Petraki F., Elefteriou P., Sygellou L., Voigt M., Giannouli M., Kennou S., Nelson J., Bradley D. D. C., Brabec C. J., Choulis S. A.: The effect of organic and metal oxide interfacial layers on the performance of inverted organic photovoltaics. Advanced Energy Materials, 3, 391-398 (2013).

DOI: $10.1002 /$ aenm.201200317 